\title{
ELIZABETH ADAMS
}

\author{
May Haikus
}

The Grove 2 (1996)

1 .

Silver green aspens

Tremble against my window.

Wild weather in May.

2.

In a child's magic painting book

A broad brush stroke converts the pristine page

Swirls of watery colour.

As in a magic painting book

A broad brush stroke changes the bare earth canvas.

Tapestries of living colour.

Haiku is a Japanese verse form consisting of seventeen syllables in three lines of five, seven, and five syllables respectively. Such a poem expresses a single idea, image or feeling. Translations from Japanese attempt to preserve the idea and the image, although it is not always possible to preserve the strict form in English. The form can, of course, be achieved when writing in English, although writers do not always restrict themselves to the pure form and rather focus on conveying the idea and the image clearly and simply. One of the most famous Japanese writers of haiku was Matsuo Kinsaku (1644-94) who later changed his name to Basho in honour of the tree given to him by a disciple. Here is one example by Basho translated by Lucien Stryk.

From the heart of the sweet peony, a drunken bee. 


\section{Poems}

\section{The Grove 9 (2001)}

1.

Draw the mountains near.

With the touch of an outstretched finger

smooth the blue blanket folds.

2.

On icy January nights

Dark giants slumber

Under cold star blankets

Patient, petrified.

Waiting for daybreak.

In icy seas and sand

Stone giants seem to sleep

Their fringed green tonsures seen.

Their feet, fifty fathoms deep.

Waiting for tideturn.

It breaks. It turns.

Day breaks. Tide turns

Day turns. Tide breaks.

Night turns into day

Moon turns the tide

Night day night day

Light day dark night

Earth turns

And turns,

And turns again.

3.

Lemon mountains

Pink mountains

Blue mountains

Green

Near mountains

Far mountains

Mystic mountains

Dream 


\title{
Seasonal haikus from the garden
}

The Grove 25 (2018-2020)

\author{
Seven tall dark pines \\ stand guard at the day's portal \\ marking the first light. \\ Frosted leaves poem \\ already penned by winter. \\ Words fled redundant. \\ Before dawn, bright moon \\ still high in sky, two blackbirds \\ vie with silver songs. \\ Plum tree awakens \\ hangs from her boughs a curtain \\ of pale pink blossom \\ Blackbird alights on \\ blossom tree gently a few \\ pink snow petals fall \\ Cool breeze caresses \\ plum tree shivers sighs lets fall \\ palest pink petals \\ Pink shawl at her feet \\ transition almost complete. \\ Now she wears copper. \\ Crystal clear water \\ Invites the light to dance on \\ its shifting surface. \\ Comes golden autumn \\ to celebrate our circuit \\ around the life source.
}


Elizabeth (Libby) Adams obtained a degree from the University of Nottingham and went on to teach Art \& Design in the UK before going to Morocco to teach English as a Foreign Language in the 1980s. From there she went to Spain where she was a lecturer in English as a Foreign Language and language teaching methodology at the University of Jaén. She was also involved in a wide range of teacher training programmes in a variety of different educational institutions. Throughout the years, running parallel to teaching, she has maintained a strong interest in creativity related to teaching and learning and other areas of life. She has worked in a variety of creative media including painting and collage for many years and had exhibitions of her art work in Morocco, Spain and the UK. Her poems have been published in various journals and publications. 